\title{
Purification and amino acid sequence of sakacin A, a bacteriocin from Lactobacillus sake Lb706
}

\author{
Askild Holck, ${ }^{1 *}$ Lars Axelsson, ${ }^{1}$ Stein-Erik Birkeland, ${ }^{2}$ Thea Aukrust ${ }^{1}$ and Hans Blom ${ }^{1}$ \\ ${ }^{1}$ MATFORSK, Norwegian Food Research Institute, Oslovn. 1, N-1430 As, Norway \\ ${ }^{2}$ Norwegian Dairies Association, Breigt. 10, 0133 Oslo, Norway
}

(Received 14 April 1992; revised 19 July 1992; accepted 26 August 1992)

\begin{abstract}
Sakacin A, a bacteriocin produced by Lactobacillus sake Lb706 and which inhibits the growth of Listeria monocytogenes, was purified to homogeneity by ammonium sulphate precipitation and ion-exchange, hydrophobicinteraction and reversed-phase chromatography. The complete amino acid sequence of sakacin $A$ was determined by Edman degradation. The bacteriocin consisted of 41 amino acid residues and had a calculated $M_{\mathrm{r}}$ of $4308 \cdot 7$, which is in good agreement with the value determined by mass spectrometry. The structural gene encoding sakacin A (sak $A)$ was cloned and sequenced. The gene encoded a primary translation product of 59 amino acid residues which was cleaved between amino acids 18 and 19 to yield the active sakacin A. Sakacin A shared some sequence similarities with other bacteriocins.
\end{abstract}

\section{Introduction}

Bacteriocins are proteinaceous compounds produced by bacteria. Bacteriocins normally inhibit the growth of closely related species. However, some bacteriocins may also inhibit the growth of pathogens and spoilage organisms during food processing and food fermentations, and may thus be of interest to the food fermentation industry.

Sakacin A, a bacteriocin produced by Lactobacillus sake Lb706, has been shown to inhibit lactic acid bacteria and Listeria monocytogenes (Schillinger \& Lücke, 1989). Inhibitory action against Listeria monocytogenes has also been observed in minced meat and comminuted cured raw pork, where viable counts were reduced by about one log cycle (Schillinger et al., 1991).

A number of bacteriocins of lactic acid bacteria have been identified, but few have been purified and

* Author for correspondence. Tel. 459970100 ; fax 4599703 33; e-mail A.L.Holck@use.uio.no, Askild.Holck@Matforsk.nlh.no.

Abbreviations: BU, bacteriocin unit; TFA, trifluoroacetic acid.

The amino acid and nucleotide sequence data reported in this paper have been submitted to EMBL and have been assigned the accession numbers P80097 (sakacin A) and Z14233 (sakA gene). characterized. These bacteriocins are often heat-stable, small polypeptides with an $M_{\mathrm{r}}$ of a few thousand. The best known is nisin, a 3400 Da polypeptide produced by Lactococcus lactis. Its structure was established by Gross \& Morell (1971). Recently, the amino acid sequences of some other bacteriocins from lactic acid bacteria have been determined. Three bacteriocins, lactococcins A, B and $M$, have been identified in Lactococcus lactis subsp. cremoris and their genes sequenced (Holo et al., 1991; Van Belkum et al., 1991 a, 1992). Hastings et al. (1991) have cloned the gene for leucocin A-UAL 187 of Leuconostoc gelidum. The gene of Lactobacillus acidophilus encoding lactacin $\mathrm{F}$ has been sequenced by Muriana \& Klaenhammer (1991). Two bacteriocins from $L b$. sake, lactocin $S$ and sakacin $P$, have been purified and sequenced by $\mathrm{N}$-terminal amino acid sequencing (Mørtvedt et al., 1991; Tichaczek et al., 1992) and a partial amino acid sequence of curvacin $A$ from Lactobacillus curvatus has been obtained (Tichaczek et al., 1992). The gene for the larger $37 \mathrm{kDa}$ helveticin $\mathrm{J}$ from Lactobacillus helveticus has also been sequenced (Joerger \& Klaenhammer, 1990).

Lactococcin A appears to function by permeabilizing the cytoplasmic membrane (Van Belkum et al., 1991 b). Information on the mode of action of other bacteriocins is scarce. Here we describe the purification and primary 
structure of sakacin A and the cloning of the corresponding structural $\operatorname{sakA}$ gene.

\section{Methods}

Bacterial strains. The sakacin A producer, Lactobacillus sake Lb706, and its non-producing and susceptible derivative $L b$. sake Lb706-B were obtained from Friedrich-Karl Lücke (Fachhochschule, Fulda, Germany). The indicator organism, chosen on the basis of its susceptibility, was identified as a Lactobacillus brevis strain by microscopy and its API sugar fermenting pattern. Lactobacillus sake L45D, a variant of $L b$. sake L45 which does not produce lactocin S (Mørtvedt \& Nes, 1990), was a laboratory strain. Lactococcus cremoris LM0230 was obtained from the Laboratory of Microbial Gene Technology, As, Norway. Lb. sake Lb706 was grown in Lactobacilli MRS broth (MRS) (de Man et al., 1960) at $25^{\circ} \mathrm{C}$.

Bacteriocin assay. Bacteriocin activity was quantified in a microtitre plate assay system (Geis et al., 1983). Twofold dilutions of bacteriocin fractions in MRS were prepared in the microtitre plates. Approximately $5 \times 10^{3}$ cells of the indicator organism were then added $(10 \mu \mathrm{l}$; $O D_{600}=0.00005$ ), giving a final volume of $110 \mu \mathrm{l}$ per well. After incubation $\left(18 \mathrm{~h}, 25^{\circ} \mathrm{C}\right)$ culture turbidity was measured spectrophotometrically at $600 \mathrm{~nm}$ in a Titertec Multiskan microplate reader. When necessary, bacteriocin fractions were adjusted to $\mathrm{pH} 6.5$ and sterilized by filtration. One bacteriocin unit (BU) was defined as the amount of bacteriocin which inhibited growth of the indicator organism by $50 \%$ as compared to a control culture without bacteriocin.

Gel filtration. Analytical gel filtration was carried out by using a FPLC Superose 12 column (Pharmacia) with a separating range of $1 \times 10^{3}-3 \times 10^{5} \mathrm{Da}$. The column was equilibrated with $50 \mathrm{~mm}$-sodium phosphate buffer ( $\mathrm{pH}$ 6.4). Gel filtration standards (Bio-Rad) ranging from 1350 to $6.7 \times 10^{5} \mathrm{Da}$ were employed for calibration of the column.

Bacteriocin purification. The bacteriocin was purified by a modification of the method of Nissen-Meyer et al. (1992). A two-litre culture of $L b$. sake Lb706 was grown to the early stationary phase and cells removed by centrifugation $\left(4000 \mathrm{~g}, 15 \mathrm{~min}, 4^{\circ} \mathrm{C}\right)$. The bacteriocin present in the supernatant fraction was concentrated by ammonium sulphate precipitation $\left(400 \mathrm{~g} \mathrm{l}^{-1}\right)$. The precipitate was pelleted by centrifugation $\left(7000 \mathrm{~g}, 20 \mathrm{~min}, 4^{\circ} \mathrm{C}\right)$ and dissolved in $250 \mathrm{ml} 20 \mathrm{~mm}$ sodium acetate, pH 4.2 (buffer A) (fraction I). Fraction I was applied to a $10 \mathrm{ml} \mathrm{S-Sepharose} \mathrm{Fast} \mathrm{Flow} \mathrm{ion-exchange} \mathrm{chromatography} \mathrm{column}$ pre-equilibrated with buffer $A$. The column was washed with 2 vols buffer $A$ and subsequently the bacteriocin was eluted in $26 \mathrm{ml} 20 \mathrm{~mm}$ sodium phosphate/1 $\mathrm{M}-\mathrm{NaCl}$ buffer, pH 5.7 (fraction II). Fraction II was made $10 \%(w / v)$ with respect to ammonium sulphate and applied to a $4.5 \mathrm{ml}$ Octyl-Sepharose CL-4B column equilibrated with $20 \mathrm{~mm}$ sodium phosphate buffer $/ 10 \%$ ammonium sulphate, $\mathrm{pH} 5.7$ (buffer $\mathrm{B}$ ). After washing with 2 vols buffer B, the bacteriocin was eluted with ethanol/20 mM-sodium phosphate buffer $(70 / 30, \mathrm{v} / \mathrm{v})$, $\mathrm{pH} 5.7$ (fraction III). The eluate was diluted fivefold in aqueous $0.1 \%$ trifluoroacetic acid (TFA) and applied to a PepRPC HR $5 / 5 \mathrm{C}_{2} / \mathrm{C}_{18}$ reversed-phase chromatography column, equilibrated with 2-propanol/ $\mathrm{H}_{2} \mathrm{O}(10 / 90$, $\mathrm{v} / \mathrm{v}$ ) containing $0 \cdot 1 \%$ TFA. Bound bacteriocin was eluted with a linear gradient of $20-50 \%$ 2-propanol containing $0.1 \%$ TFA (fraction IV). The diluted bacteriocin was rechromatographed on the same column. The purified bacteriocin was stable in $30 \%(\mathrm{v} / \mathrm{v})$ 2-propanol containing $0.1 \%$ TFA at $-20^{\circ} \mathrm{C}$.

Mass analysis. Mass analysis of the purified bacteriocin was carried out on a Biolon 20 mass analyser (Applied Biosystems) as described by Sørensen et al. (1990). Approximately $10 \mu \mathrm{g}$ of purified, vacuumevaporated bacteriocin was dissolved in $50 \mu \mathrm{l}$ TFA containing $20 \%$ acetonitrile, and $5 \mu \mathrm{l}$ of this solution was used in the experiment. Data were accumulated by the mass analyser for $2 \mathrm{~h}$ at $16 \mathrm{kV}$.

Amino acid sequencing. A gas-phase 477A automatic microsequencer (Applied Biosystems) with an online 120A phenylthiohydantoin amino acid analyser was used (Cornwell et al., 1988).

Recombinant DNA techniques. The basic cloning techniques of Sambrook et al. (1989) were used. Oligonucleotide probes were synthesized on an Applied Biosystems synthesizer 381A. The probes were end-labelled with ${ }^{32} \mathrm{P}$ using a terminal transferase end-labelling kit (Amersham). Plasmid DNA from $L b$. sake Lb706 was digested with various restriction endonucleases and the resulting fragments separated on agarose gels, blotted onto nylon filters and hybridized with sakacin A probes. The $1.4 \mathrm{~kb}$ EcoRI fragment hybridizing to the oligonucleotide probes was purified from agarose gels using DEAE nitrocellulose filter strips (Dretzen et al., 1981) and cloned in E. coli DH $5 \alpha$ using the $L b$. plantarum/Lb. sake/E. coli shuttle vector PLPV 106 . This vector is composed of the erythromycin resistance gene of $L b$. reuteri (Axelsson et al., 1988), replication determinants obtained from the cryptic $L b$. plantarum plasmid p256 (Cosby et al., 1989) and the pUC19 origin of replication. Both strands of the $1.4 \mathrm{~kb}$ EcoRI fragment were sequenced by the dideoxy chain-termination method of Sanger $e t$ al. (1977), using synthetic oligonucleotide primers (primer walking) and the Sequenase version 2.0 DNA sequencing kit (United States Biochemical Corporation).

Computer analyses were carried out on an IBM personal computer employing the DNASIS sequence analysis program (Pharmacia) and on a microVAX 3400 computer employing the GCG program package (Devereux et al., 1984).

\section{Results}

\section{Production of sakacin A}

The production of sakacin A was investigated during growth of $L b$. sake Lb706 in MRS (Fig. 1). The results indicated that sakacin A production was constitutive during exponential-phase growth and ceased as the cells entered the stationary phase, with subsequent loss of activity. Similar results were obtained when the growth medium was buffered to $\mathrm{pH} 6.5$ with $0.1 \mathrm{M}$-potassium phosphate or to $\mathrm{pH} 6.0$ with $0.2 \mathrm{M}$-MOPS.

Consequently, the bacteriocin was harvested as the cells entered the stationary phase.

\section{Purification of sakacin A}

Sakacin A was purified to homogeneity by ammonium sulphate precipitation, and sequential cation-exchange, hydrophobic-interaction and reversed-phase chromatography (Table 1). Overall, a more than 9000 -fold increase in specific activity to a final value of $250 \mathrm{BU}(\mu \mathrm{g}$ protein $)^{-1}$ was obtained. Approximately $2.6 \times 10^{5}$ molecules per indicator cell thus represented $1 \mathrm{BU}$ in the microtitre plate assay. The purified bacteriocin appeared homogeneous when subjected to FPLC reversed-phase chromatography. Likewise, a single band was observed 


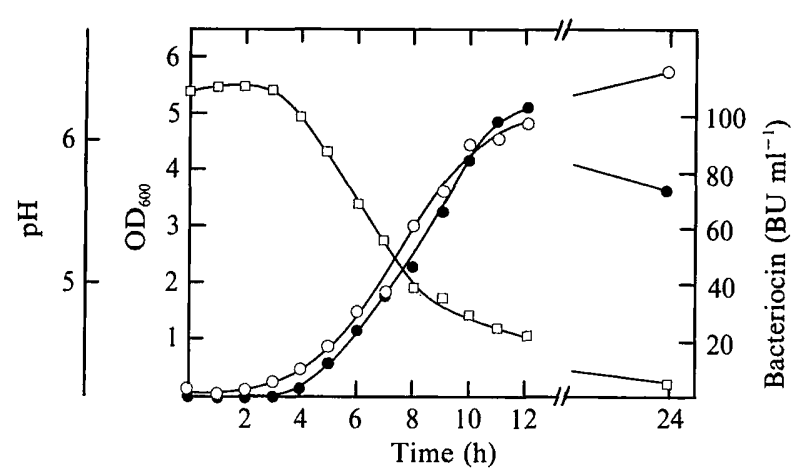

Fig. 1. Production of sakacin A by $L b$. sake Lb706 grown in MRS. $\bullet$, Bacteriocin activity; $O, \mathrm{OD}_{600} ; \square, \mathrm{pH}$.

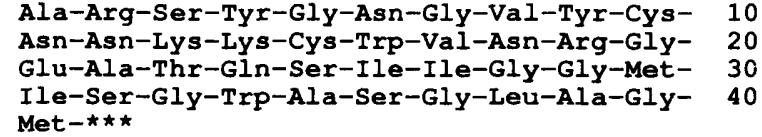

Fig. 2. Amino acid sequence of sakacin A.

when sakacin A was subjected to SDS gel electrophoresis.

The complete amino acid sequence of the purified bacteriocin was determined by Edman degradation (Fig. 2). Uncertain amino acid determinations in positions 2 , 10,15 and 40 were verified by sequencing of the cloned gene (see below). Sakacin A consisted of one polypeptide chain of 41 amino acid residues with a calculated $M_{\mathrm{r}}$ of 4308.7. No unusual amino acid residues such as lanthionins were found. The calculated $M_{\mathrm{r}}$ was almost identical to the value of 4309.6 determined by plasma desorption mass spectrometry. The extra $1 \mathrm{Da}$ in the latter analysis probably originated from protonation of the polypeptide during desorption (Tsarbopoulos, 1989).

To determine whether sakacin A existed as an aggregate in solution, the bacteriocin was subjected to gel filtration. Supernatant after growth in MRS was precipitated with ammonium sulphate and the bacteriocin was dissolved in $50 \mathrm{~mm}$-sodium phosphate buffer $\mathrm{pH} 6.4$ and

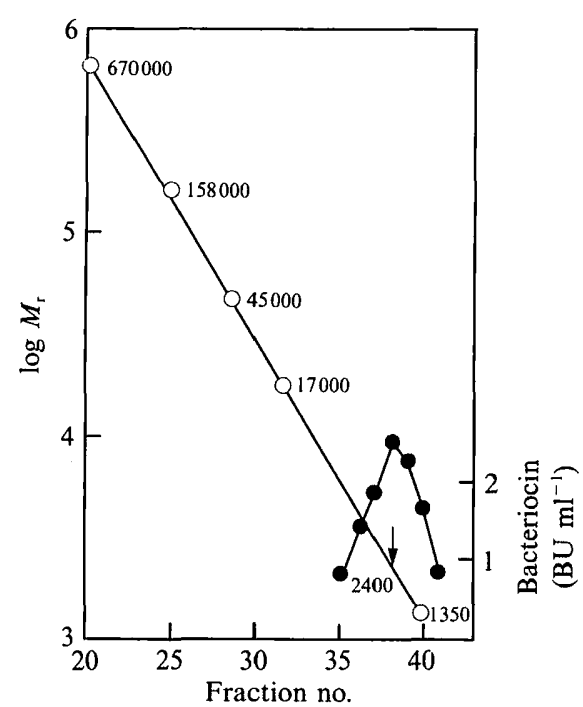

Fig. 3. $M_{\mathrm{r}}$ of sakacin A determined by gel filtration. Ammoniumsulphate-concentrated growth supernatant was dissolved in $50 \mathrm{~mm}$ sodium phosphate buffer $\mathrm{pH} 6.4$ and subjected to Superose 12 gel filtration. The elution positions of the reference proteins $(O)$ are superimposed on the activity profile of sakacin A (•).

subjected to FPLC Superose 12 gel filtration chromatography at the same pH (Fig. 3). The bacteriocin eluted at an $M_{\mathrm{r}}$ of approximately 2400 . This suggested that it exists as a monomer in the medium. Similar results were obtained when the gel filtration chromatography was performed at $\mathrm{pH} 4.5$ (results not shown).

\section{Cloning and DNA sequencing of the sakacin A structural gene}

Two degenerate 29-mer oligonucleotide probes, deduced from the amino acid sequence of sakacin $A$, both hybridized with a $1.4 \mathrm{~kb}$ EcoRI fragment, originating from the larger (approx. $60 \mathrm{~kb}$ ) of the two plasmids present in $L b$. sake Lb706. The EcoRI fragment was cloned in $E$. coli DH5 $\alpha$ using the shuttle vector pLPV106 and sequenced. The structural gene, sakA, consisted of an open reading frame of $177 \mathrm{bp}$ encoding a primary

Table 1. Purification of sakacin $A$

\begin{tabular}{lcccc}
\hline \hline & $\begin{array}{c}\text { Total } \\
A_{280}\end{array}$ & $\begin{array}{c}\text { Total } \\
\text { activity } \\
\text { Purification stage }\end{array}$ & $\begin{array}{c}\text { Specific } \\
\text { activity* }\end{array}$ & $\begin{array}{c}\text { Yield } \\
\text { (\%) }\end{array}$ \\
\hline Culture supernatant & 61050 & 259000 & 4.2 & 100 \\
(NH S $_{2} \mathrm{SO}_{4}$ conc (Fr I) & 2725 & 248400 & 91 & 96 \\
S-Sepharose chrom. (Fr II) $_{\text {Octyl-Sepharose chrom. (Fr III) }}^{73}$ & 36500 & 500 & 14 \\
Rev.-phase FPLC (Fr IV) & 27 & 131500 & 4830 & 51 \\
\hline \hline
\end{tabular}

*Specific activity $=$ total activity/total $\boldsymbol{A}_{\mathbf{2 8 0}}$. 


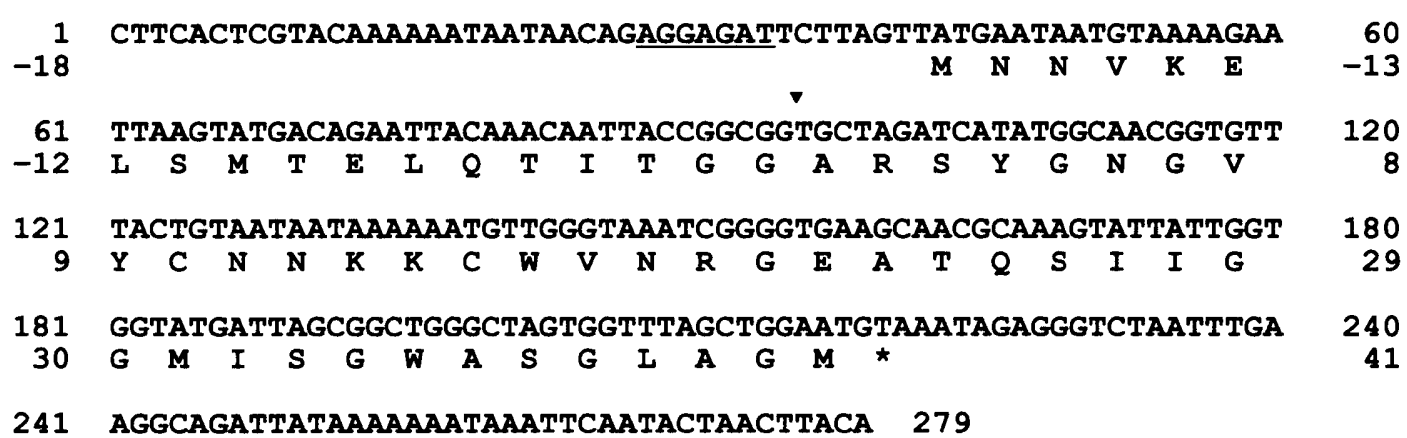

Fig. 4. Nucleotide sequence of the sakA gene. Only the antisense strand (mRNA-like) is shown. The putative ribosome-binding site is underlined. The downward-pointing arrowhead indicates the cleavage site to yield the mature sakacin A.

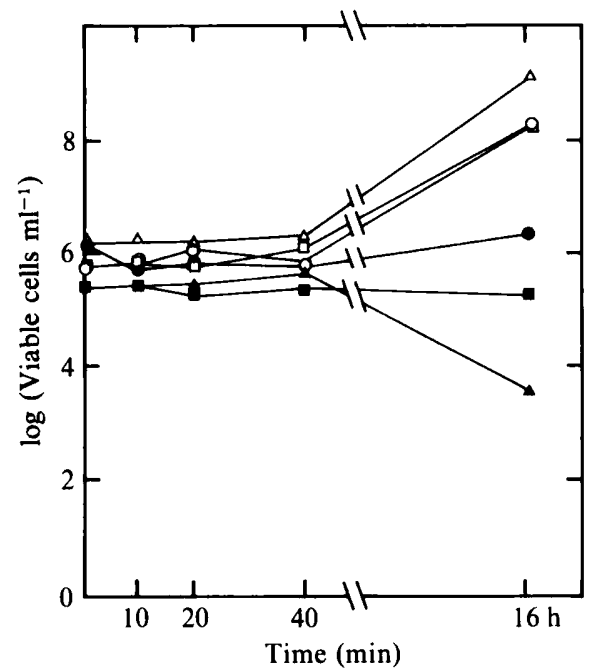

Fig. 5. Effect of sakacin A on different lactic acid bacteria. The cells $\left(10^{4}\right)$ were incubated with 480 BU of purified bacteriocin for various times and the number of colony-forming units was determined. $\square, L b$. sake $\mathrm{Lb} 706$ + sakacin $\mathrm{A} ; \mathbf{\square}, L b$. sake $\mathrm{Lb} 706 \mathrm{~B}+\operatorname{sakacin} \mathrm{A} ; \boldsymbol{\Delta}, L b$. brevis + sakacin $\mathrm{A} ; \triangle$, Lb. brevis minus sakacin $\mathrm{A} ; \bullet$, Lb. sake $\mathrm{L} 45 \mathrm{D}+$ sakacin A; O, L. cremoris LM0230 + sakacin A.

translation product of 59 amino acid residues (Fig. 4). Cleavage of the polypeptide chain after amino acid 18 would yield the mature sakacin $\mathrm{A}$ as determined by amino acid sequencing. A putative Shine-Dalgarno sequence was located upstream of the gene.

\section{Effect of sakacin $A$}

To investigate the effect of sakacin A, different lactic acid bacteria were exposed to a fixed amount of bacteriocin for various time (Fig. 5). No effect on survival of cells was observed for short incubations with sakacin A. However, when cells were incubated with the bacteriocin for $16 \mathrm{~h}$, different effects were clearly visible. For the most sensitive strain, Lb. brevis, which was used as the indicator organism, a nearly 100 -fold decrease in viable cell numbers was observed, whereas for $L b$. sake Lb706-B and $L b$. sake L45D, a bacteriostatic effect was observed. Lactococcus cremoris LM0230, which in the microtitre assay was sensitive to sakacin A, was apparently capable of overcoming growth inhibition during longer periods of incubation.

\section{Discussion}

In contrast to what has been stated earlier (Schillinger $\&$ Lücke, 1989), sakacin A activity was present throughout the exponential phase of growth and not solely as the cells entered the late exponential growth phase or early stationary phase. In this respect sakacin A differs from the very similar bacteriocin curvacin A from $L b$. curvatus LTH1174. Curvacin A is only produced in the late exponential growth phase (Tichaczek et al., 1992).

Many of the bacteriocins of lactic acid bacteria are polypeptides of $M_{\mathrm{r}}$ in the range $3000-6000$, with a surplus of positively charged amino acid residues and showing some hydrophobic characteristics. Consequently, purification schemes often involve ion-exchange chromatography and hydrophobic-interaction chromatography. During purification, an increase in bacteriocin activity was observed after Octyl Sepharose (hydrophobic-interaction) chromatography and after reversedphase chromatography. The reason for this increase is unknown.

Sakacin A was purified more than 9000-fold to homogeneity and sequenced. The $M_{\mathrm{r}}$ calculated from the amino acid sequence was almost identical to that determined by plasma desorption mass spectrometry and confirmed the correctness of the proposed amino acid sequence. This also seems to preclude the possibility of post-translational covalent modifications of the polypeptide such as glycosylation, although non-covalent interactions may occur. In addition, the similarity between 
(a)

\begin{tabular}{|c|c|}
\hline Curvacin A & 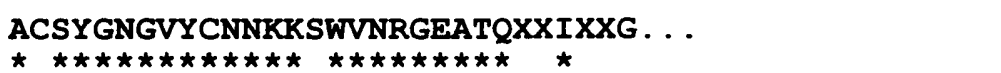 \\
\hline Sakacin A & 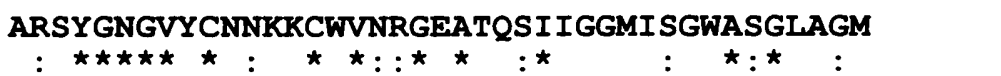 \\
\hline Sakacin $\mathbf{P}$ & 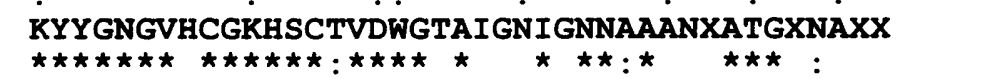 \\
\hline Pediocin PA-1 & 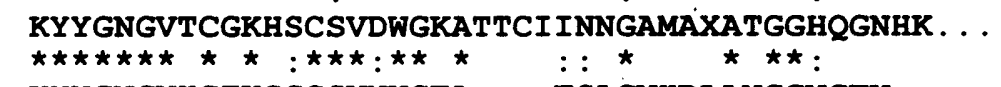 \\
\hline seucoc & KYYGNGVHCTKSGCSVNWGEA----FSAGVHRLANGGNGEW \\
\hline
\end{tabular}

(b)

Sakacin A

ARSYGNGVYCNNKKCWVNRGEATQSIIGGMIS----GWASGLAGM

Lactococcin A KLTFIQSTAAGDLYYNTNTHKYVYQQTQNAFGAAANTIVNGWMGGAAGGFGLHH

Fig. 6. Comparison of the amino acid sequence of sakacin A with (a) curvacin A, sakacin P, pediocin PA-1 and leucocin A, and (b) lactococcin A. Identical amino acids are indicated by asterisks and conservative changes are shown by colons. Putative amphiphilic $\alpha$-helices are underlined.

the calculated and the determined $M_{\mathrm{r}}$ values indicated that the cysteine residues existed in the reduced state and were not engaged in intramolecular cystine bridging. Furthermore, when sakacin A was heated with $1 \mathrm{~mm}-\beta$ mercaptoethanol at $80^{\circ} \mathrm{C}$ for $10 \mathrm{~min}$ to ensure that the thiol residues existed in the reduced state, no change in activity was observed (results not shown). This indicates that the oxidation state of the cysteine residues may not be important for the bacteriocin activity. In contrast, the two cysteine residues of leucocin A-UAL 187 are thought to form a cystine bridge, although reduction without loss of activity can occur (Hastings et al., 1991).

The active sakacin $\mathrm{A}$ is apparently processed from a longer primary translation product, with the precursor sequence sharing some similarities with precursor sequences from other bacteriocins (Kok et al., 1992).

The charged amino acid residues were all located in the N-terminal hydrophilic part of the polypeptide chain, whilst the more hydrophobic C-terminal part consisted of pairs of hydrophobic amino acid residues regularly spaced by pairs of the hydrophilic amino acid residues glycine and serine. No significant homology was found with other proteins. However, sakacin A shared some homology, especially in the $\mathrm{N}$-terminal region, with the newly sequenced bacteriocins leucocin A-UAL 187 (Hastings et al., 1991), pediocin PA-1 (Nieto Lozano et al., 1992) and sakacin P (Tichaczek et al., 1992) and appeared to be very similar to the partly sequenced curvacin A (Tichaczek et al., 1992) (Fig. 6). The Nterminal similarities between sakacin $A$, sakacin $P$ and curvacin A may be reflected in their common antagonistic spectrum (Scillinger \& Lücke, 1989; Tichaczek et al., 1992). These sequence similarities indicate that bacteriocins may be grouped into families as was suggested by Nieto Lozano et al. (1992). The mechanism of action of this group of bacteriocins is at present not known.
Sakacin-A-susceptible strains appear to vary widely in their degree of sensitivity to the bacteriocin. In some cases only a bacteriostatic effect was observed, whereas in other cases a drop in viable cell counts was detected. When lactococcin A was mixed with a susceptible strain and the fluorescent dye propidium iodide, influx of fluorescent dye into the sensitive cells was observed by flow cytometry ( $\mathrm{H}$. Holo, personal communication). This indicated permeabilized and dead cells. No influx of propidium iodide was observed when similar experiments were carried out with sakacin A (results not shown).

Amphiphilic $\alpha$-helices often exist as transmembrane regions in pore-forming proteins (Ojcius \& Young, 1991). Putative amphiphilic $\alpha$-helix structures were detected in sakacin A between amino acids 26 and 41 (Rao \& Argos, 1986) (Fig. 6b), the region encompassing the regularly spaced hydrophobic and hydrophilic amino acids. In this respect sakacin A showed similarities with lactococcin A, which is a cytoplasmic membrane-permeabilizing molecule (Van Belkum et al., 1992) spanning the cytoplasmic membrane by an amphiphilic $\alpha$-helix (Kok et al., 1992). Since it was not possible to demonstrate pore formation with sakacin $A$, the significance of the putative amphiphilic transmembrane helix $A$ is unknown.

We want to thank Dr U. Schillinger and Dr F.-K. Lücke for supplying the bacteriocin-producing $L b$. sake Lb706 and the corresponding cured variant $L b$. sake Lb706-B, Dr K. Sletten at the Department of Biochemistry, University of Oslo, for carrying out the automatic amino acid sequencing, J. Thomsen, Department of Structural Chemistry, Novo Nordisk A/S, Denmark, for the use of the Biolon 20 mass analyser, and S. Bayne, Applied Biosystem Division of KEBO Lab, Ballerup, for analysing the peptide samples on the Biolon 20 mass analyser. Also we want to thank Dr I. F. Nes and Dr J. NissenMeyer for fruitful discussions. Finally, we are grateful to J. Reseland 
for help with flow cytometer experiments and Birgitta Baardsen for technical assistance.

\section{References}

Axelsson, L. T., Ahrné, S. E. l., Andersson, M. C. \& StÅhl, S. R. (1988). Identification and cloning of a plasmid-encoded erythromycin resistance determinant from Lactobacillus reuteri. Plasmid 20, 171-174.

Cornwell, G. G., Sletten, K., Johansson, B. \& Westermark, P. (1988). Evidence that the amyloid fibril protein in senile systemic amyloidosis is derived from normal prealbumin. Biochemical and Biophysical Research Communications 154, 648-653.

Cosby, W. M., Axelsson, L. T. \& Dobrogosz, W. J. (1989). Tn917 transposition in Lactobacillus plantarum using the highly temperature-sensitive plasmid pTVITs as a vector. Plasmid 22, 236-243.

DevereuX, J., Haeberli, P. \& Smithies, O. (1984). A comprehensive set of sequence analysis programs for the VAX. Nucleic Acids Research 12, 387-395.

Dretzen, G., Bellard, M., Sassone-Corsi, P. \& Chambon, P. (1981). A reliable method for the recovery of DNA fragments from agarose and acrylamide gels. Analytical Biochemistry 112, 295-298.

GeIS, A., JASJIT, J. \& TeUber, M. (1983). Potential of lactic streptococci to produce bacteriocin. Applied and Environmental Microbiology $\mathbf{4 5}$ 205-211.

Gross, E. \& MoRelL, J. (1971). The structure of nisin. Journal of the American Chemical Society 93, 4634-4635.

Hastings, J. W., Sailer, M., Johnson, K., Roy, K. L., Vederas, J. C. \& STILeS, M. E. (1991). Characterization of Leucocin A-UAL 187 and cloning of the bacteriocin gene from Leuconostoc gelidum. Journal of Bacteriology 173, 7491-7500.

Holo, H., Nilssen, Ø. \& Nes, I. F. (1991). Lactococcin A, a new bacteriocin from Lactococcus lactis subsp. cremoris: isolation and characterization of the protein and its gene. Journal of Bacteriology 173, 3879-3887.

Joerger, M. C. \& Klaenhammer, T. R. (1990). Cloning, expression, and nucleotide sequence of the Lactobacillus helveticus 481 gene encoding the bacteriocin Helveticin J. Journal of Bacteriology 172, 6339-6347.

KoK, J., Nes, I. F., Holo, H., Van Belkum, M. J. \& HaAndrikman, A. (1992). Non-nisin bacteriocins in lactococci: biochemistry, genetics and mode of action. In Bacteriocins of Lactic Acid Bacteria, Edited by D. G. Hoover \& L. R. Steenson. New York: Academic Press (in the Press).

MAN, J. C. DE, Rogosa, M. \& Sharpe, M. E. (1960). A medium for the cultivation of lactobacilli. Journal of Applied Bacteriology 23, 130 135

Muriana, P. M. \& Klaenhammer, T. R. (1991). Cloning, phenotypic expression, and DNA sequence of the gene for Lactacin $F$, an antimicrobial peptide produced by Lactobacillus spp. Journal of Bacteriology 173, 1779-1788.

MøRTVEDT, C. I. \& NES, I. F. (1990). Plasmid-associated bacteriocin production by a Lactobacillus sake strain. Journal of General Microbiology 136, 1601-1607.
Mørtvedt, C. I., Nissen-Meyer, J., Sletten, K. \& Nes, I. F. (1991). Purification and amino acid sequence of Lactocin $\mathrm{S}$, a bacteriocin produced by Lactobacillus sake L45. Applied and Environmental Microbiology 57, 1829-1834.

Nieto lozano, J. C. Nissen-Meyer, J., Sletten, K., Pelaz., C. \& Nes, I. F. (1992). Purification and amino acid sequence of a bacterocin produced by Pediococcus acidilactici. Journal of General Microbiology 138, 1985-1990.

Nissen-Meyer, J., Holo, H., Håvardstein, L. S., Sletten, K. \& Nes, I. F. (1992). A novel lactococcal bacteriocin whose activity depends on the complementary action of two peptides. Journal of Bacteriology 174, 5686-5692.

OJCIUS, D. M. \& YounG, J. D.-E. (1991). Cytolytic pore-forming proteins and peptides: is there a common structural motif? Trends in Biochemical Sciences 16, 225-229.

RAO, J. K. M. \& ARGOS, P. (1986). A conformational preference parameter to predict helices in integral membrane proteins. Biochimica et Biophysica Acta 869, 197-214.

Sambrook, J., Fritsch, E. F. \& Maniatis, T. (1989). Molecular Cloning: a Laboratory Manual, 2nd edn. Cold Spring Harbor, NY: Cold Spring Harbor Laboratory.

SANGer, F., Nicklen, S. \& Coulson, R. (1977). DNA sequencing with chain-terminating inhibitors. Proceedings of the National Academy of Sciences of the United States of America 74, 5463-5467.

SCHILlINGER, U. \& LÜCKE, F.-K. (1989). Antibacterial activity of Lactobacillus sake isolated from meat. Applied and Environmental Microbiology 55, 1901-1906.

SCHILlinger, U., KAYA, M. \& LÜCKE, F.-K. (1991). Behaviour of Listeria monocytogenes in meat and its control by a bacteriocinproducing strain of Lactobacillus sake. Journal of Applied Bacteriology 70, 473-478

Sørensen, H. H., Thompsen, J., Bayne, S., HøjRup, P. \& RoepstorfF, P. (1990). Strategies for determination of disulphide bridges in proteins using plasma desorption mass spectrometry. Biomedical and Environmental Mass Spectrometry 19, 713-720.

Tichaczex, P. S., Nissen-Meyer, J., Nes, I. F., Vogel, R. F. \& Hammes, W. P. (1992). Characterization of the bacteriocins Curvacin A from Lactobacillus curvatus LTH1174 and Sakacin P from L. sake LTH673. Systematic and Applied Microbiology (in the Press).

Tsarbopoulos, A. (1989). Plasma desorbtion mass spectrometry of natural and recombinant peptides and proteins. Peptide Research 2 , $258-266$.

Van Belkum, M. J., Hayema, B. J., Jeeninga, R. E., KoK, J. \& VENEMA, G. (1991 a). Organization and nucleotide sequences of two lactococcal bacteriocin operons. Applied and Environmental Microbiology 57, 492-498.

Van Belkum, M. J., KoK, J., Venema, G., Holo, H., Nes, I. F., KONINGS, W. N. \& ABEE, T. (1991b). The bacteriocin Lactococcin A specifically increases permeability of lactococcal cytoplasmic membranes in a voltage-independent, protein-mediated manner. Journal of Bacteriology 173, 7934-7941.

Van Belkum, M. J., KoK, J. \& Venema, G. (1992). Cloning, sequencing, and expression in Escherichia coli of $\operatorname{lonB}$, a third bacteriocin determinant from the lactococcal bacteriocin plasmid p9B4-6. Applied and Environmental Microbiology 58, 572-577. 